\title{
The Effect of Sulphanilamide on the Metabolism of Calcium, Carbonate, Phosphorus, Chloride and Nitrogen in the Laying Hen
}

\author{
BY C. TYLER \\ Department of Agricultural Chemistry, University of Reading
}

(Received 7 January 1950)

The experiments of Mann \& Keilin (1940) clearly showed that sulphanilamide is a powerful inhibitor of carbonic anhydrase. Later, Benesch, Barron \& Mawson (1944) studied the effect of sulphanilamide on laying hens. These workers showed that sulphanilamide feeding resulted in the production of thin-shelled or shell-less eggs and they attributed this to the inhibition of the carbonic anhydrase in the shell gland. This work was extended by Scott, Jungherr \& Matterson (1944) who tested different dosages and found that the decrease in shell thickness was proportional to the sulphanilamide dose. Other workers have taken up this problem and the literature was recently reviewed by Tyler (1948-9).

The purpose of the experiments now to be described was to consider, in greater detail than before, the effect of sulphanilamide on the laying hen. To do this, certain mineral balances and the nitrogen balance were studied, and a fairly detailed investigation of the egg itself, particularly of the shell, was made.

\section{METHODS}

Birds. Four Rhode Island Red hens, which had lived in battery cages from the time they began to lay as pullets, were used. They quickly settled down when transferred to the metabolism cages and were soon in full lay.

Cages. The metabolism cages were a modified version of those already described by Willcox (1934).

\section{Plan of experiment}

General. There were six periods each of 7 days. The first two, $\mathrm{C}_{\mathrm{I}}$ and $\mathrm{C}_{2}$, were identical control periods; next came $\mathrm{S}_{3}$ and $\mathrm{S}_{4}$, again identical, but differing from the control in that sulphanilamide was given. By this arrangement it was possible to study time-lag effects. Period $\mathrm{R}_{5}$ was a period in which the original control ration was fed, but it must be looked upon as a recovery period rather than as another control period. Finally, there was period PS6. In bacteriological work it has been recognized for some time that $p$-aminobenzoic acid counteracts the effects of sulphanilamide. Therefore, as an addition to the main experiment, $p$-aminobenzoic acid was ${ }^{\circ}$ fed either alone or with sulphanilamide in this last period. Birds nos. I and 2 received the two compounds, birds nos. 3 and 4 the $p$-aminobenzoic acid alone.

Ration. 'The percentage composition of the basal ration was : middlings 34 , maize meal 
(yellow) 20, barley meal 15 , oats $1_{5}$, fish meal 6, dried grass 6, dried yeast 2, dried skim milk 2. To roo parts of this mixture was added one part of cod-liver oil.

Feeding. At feeding time $140 \mathrm{~g}$. basal ration were mixed with a supplement containing $5 \mathrm{~g}$. calcium carbonate and $0.3 \mathrm{~g}$. sodium chloride with or without the addition of the drugs, and the mixture was made into a moist crumbly mash by adding $80 \mathrm{ml}$. water. The mixture was given to each bird daily, along with $400 \mathrm{ml}$. drinking water. The only variation from period to period lay in the composition of the supplements. The analysis of the rations as fed and details of the drugs supplied are given in Table I.

Table $\mathrm{I}$. The analytical composition of the rations and the additions of sulphanilamide and $\mathrm{p}$-aminobenzoic acid, expressed as percentages of dry matter

\begin{tabular}{|c|c|c|c|c|c|c|}
\hline Periods & Calcium & $\begin{array}{l}\text { Carbonate } \\
\text { (as } \mathrm{CO}_{2} \text { ) }\end{array}$ & Phosphorus & Chloride & Nitrogen & $\begin{array}{c}\text { Sulphanilamide (S) } \\
\text { and } p \text {-aminobenzoic } \\
\text { acid (P) }\end{array}$ \\
\hline $\mathrm{C}_{I}$ & $\begin{array}{r}\text { I.98 }\end{array}$ & 1.63 & 0.87 & $0.3^{8}$ & $2 \cdot 64$ & - \\
\hline $\mathrm{C}_{2}$ & 1.94 & 1.63 & 0.88 & 0.38 & $2 \cdot 54$ & - \\
\hline $\mathbf{S}_{\mathbf{3}}$ & $1 \cdot 92$ & 1.65 & 0.90 & $0.3^{8}$ & $2 \cdot 68$ & $0.03 \mathrm{~S}$ \\
\hline$S_{4}$ & $x \cdot 84$ & $\times 63$ & 0.88 & 0.38 & $2 \cdot 70$ & $0.03 \mathrm{~S}$ \\
\hline $\mathbf{R}_{5}$ & 1.86 & 1.65 & 0.89 & 0.39 & $2 \cdot 68$ & - \\
\hline PS6 (birds nos. $x$ and 2) & $x \cdot 88$ & 1.66 & 0.90 & 0.38 & $2 \cdot 66$ & $0.03 \mathrm{~S}$ and $0.03 \mathrm{P}$ \\
\hline PS6 (birds nos. 3 and 4 ) & $x \cdot 86$ & $1 \cdot 65$ & 0.87 & 0.38 & $2 \cdot 70$ & $0.03 \mathrm{P}$ \\
\hline
\end{tabular}

The variations between periods were caused chiefiy by different consignments of basal ration.

Collection and treatment of materials. Zero hour was taken as 7 a.m., at which time food residues and droppings were removed and fresh food and water given. Eggs were collected and weighed as soon as possible after they were laid. Food residues were weighed, dried and reweighed. Droppings from each bird were mixed into a homogeneous paste and weighed. A sample was then withdrawn and immediately put into a small crystallizing dish fitted with a Bakelite lid. The remainder of the droppings was weighed again, dried at $105^{\circ}$ for $24 \mathrm{hr}$., weighed, ground and bottled. Samples of wet droppings were weighed as quickly as possible for the immediate determination of carbonate (as carbon dioxide), chloride and nitrogen.

The outward appearance of each egg, such as colour and smoothness, was described, and then after it had remained in a desiccator for a fortnight, its appearance under the candling lamp was examined. The eggs were afterwards stored in a refrigerator until such time as they could be analysed. Shell and contents were analysed separately. The washed and dried shells (with membranes) were weighed before analysis and the contents were converted to a homogeneous cream in a Waring Blendor before they were made up to volume.

Despite all precautions a few eggs laid, particularly during the sulphanilamide periods, were broken. When salvage was not possible the contents had to be mixed with the droppings, but a portion of the shell was usually saved, although the bird had often eaten some of it.

\section{Methods of analysis}

Droppings. The dry droppings were ashed, the ash extracted with hot dilute hydrochloric acid and the extract made up to volume. Calcium was then determined in a portion of this by precipitation of the oxalate followed by solution of the precipitate 
in sulphuric acid and titration with potassium permanganate. For phosphorus determinations the dry droppings were oxidized with a mixture of concentrated sulphuric and nitric acids, the clear liquid was neutralized with ammonium hydroxide and made up to volume. Phosphorus was precipitated from a portion of this as strychnine phosphomolybdate and determined gravimetrically using a modification of the EmbdenFetter method as described by Peters \& Van Slyke (1932). Davies's (1932) method was used for chlorides, and the Kjeldahl process for nitrogen, each being carried out on the fresh droppings. Fresh droppings were also used for the carbonate determination which was carried out by means of a Collins's ( 1906$)$ calcimeter. The calcimeter had previously been carefully calibrated using different quantities of Iceland spar.

Egg-shells. The method of analysis for calcium was the same as for droppings, except that the shell was simply dissolved in hydrochloric acid and the solution filtered and made up to volume. A wet oxidation with perchloric and nitric acids (Gerritz, 1935) was used to give a solution in which phosphorus was determined colorimetrically, using ammonium vanadate, by the method of Koenig \& Johnson (1942) as modified by Kitson \& Mellon (1944).

Egg contents. The wet oxidation with perchloric and nitric acids (Gerritz, 1935) was used to give a solution in which both calcium and phosphorus could be determined. Calcium was precipitated as oxalate, and ceric sulphate was used for the titration with the ferrous complex of $o$-phenanthroline as indicator (Wheatley, 1944). Phosphorus was determined colorimetrically using ammonium vanadate. Chlorides and nitrogen were determined by the same methods as those used for droppings. No carbonate determinations were made.

\section{Treatment of the data}

According to the plan of the experiment, there were six periods, each lasting 7 days, and although it was important to use all the 7 days to obtain information about the quickness with which changes occurred on a change of diet, it was nevertheless better to reject the ist day of each period when mean values for each period were being compared. Thus, all mean values given here for periods refer to the last 6 days of the periods.

Bird no. I failed to eat the whole of her ration and this had its effect on the retention values. Furthermore, this bird was very upset by the sulphanilamide and her egglaying cycle was so disturbed that on more than one occasion she laid two eggs in one $24 \mathrm{hr}$. period. She was therefore excluded as far as statistical analysis of the data was concerned but, where possible, it is indicated whether the results obtained with her conformed to the general picture as shown by the other birds.

As stated earlier, in period PS 6 two of the birds were given sulphanilamide with $p$-aminobenzoic acid and the other two received $p$-aminobenzoic acid alone. The data concerning this period are shown in the appropriate tables, but they are not included in the statistical analysis.

The statistical analysis of the data was therefore confined to the first five periods and to birds nos. 2-4. 'The analysis of variance was used, taking mean values per birdperiod and using the interaction of birds $\times$ periods as the error term. It was only after 
much preliminary work with the full data for individual days as distinct from period means that the above method was finally chosen as being satisfactory for the purpose of this experiment. The statistical analysis is not shown in the tables, but only the significance of the difference between successive period means. For the most part differences between birds have been ignored.

\section{Definition of terms}

Poultry droppings consist of faeces and urine mixed together. For this reason it is incorrect to refer to the difference between intake values and values for droppings as absorbed material. It is customary, therefore, to name the difference 'retention', and this practice will be followed here. Retention by this definition implies that material in the egg is 'retained', and if egg material is deducted from the retention value, the so-called balance remains.

\section{RESULTS}

General. Throughout the experiment birds nos. 2 and 3 ate all their ration in a few hours, but bird no. 4 took a much longer time over it and towards the end of the experiment was leaving a little food each day. Bird no. I was quite exceptional in that she left some food almost every day and particularly in periods $\mathrm{S}_{3}$ and $\mathrm{S}_{4}$ when sulphanilamide was given. The birds appeared to be in good health and regular weighings showed that weight changes were very small.

Egg production. The details of egg production are shown in Table 2. There were no significant differences between periods for birds nos. 2, 3 and 4 . On the other hand, bird no. I laid fewer eggs when given sulphanilamide, but this may be of little significance. On the whole, the results agree with those of Scott et al. (1944), who stated that for this level of dosage egg production was not affected. In period PS6 egg production did not appear to be influenced by $p$-aminobenzoic acid either with or without sulphanilamide.

Table 2. Number of eggs laid in the different periods

\begin{tabular}{|c|c|c|c|c|c|c|c|c|c|c|}
\hline \multirow{2}{*}{$\begin{array}{l}\text { Bird } \\
\text { no. }\end{array}$} & \multicolumn{10}{|c|}{ Period } \\
\hline & $C_{I}$ & & $\mathrm{C}_{2}$ & & $s_{3}$ & & $S_{4}$ & & $\mathbf{R}_{5}$ & PS6 \\
\hline $\begin{array}{l}2 \\
3\end{array}$ & $\begin{array}{l}5 \\
3\end{array}$ & & $\begin{array}{l}4 \\
3\end{array}$ & & $\begin{array}{l}4 \\
3\end{array}$ & & $\begin{array}{l}4 \\
3(\mathrm{r})\end{array}$ & & $\begin{array}{l}4 \\
2\end{array}$ & $\begin{array}{l}4 \\
2\end{array}$ \\
\hline 4 & 3 & & 4 & & 4 & & $3(1)$ & & 4 & 4 \\
\hline $\begin{array}{c}\text { Mean } \\
I\end{array}$ & $\begin{array}{l}3 \cdot 7 \\
4\end{array}$ & N.S. & $\begin{array}{l}3.7 \\
4\end{array}$ & N.S. & $\begin{array}{l}3.7 \\
3(1)\end{array}$ & N.S. & $\begin{array}{l}3 \cdot 3 \\
2(1)\end{array}$ & N.S. & $\begin{array}{l}3 \cdot 3 \\
4(\mathrm{r})\end{array}$ & $\overline{2(1)}$ \\
\hline
\end{tabular}

Notes. Figures in parentheses indicate soft-shelled eggs, as distinct from thin-shelled. N.S. Not significant at $P=0.05$. The statement refers to the difference between the two values on either side of it. In subsequent tables * * or *** indicate similarly that the difference is significant at $P=0.05, P=0.01$ or $P=0.001$. For reasons given on p. 114 no mean is quoted for period PS 6 .

Shell weight. Fluctuations in egg-content weight from period to period were negligible and thus the minor fluctuations in total egg weight were almost entirely due to changes in shell weight. Table 3 gives the values for shell weight. It will be observed that in periods $\mathrm{S}_{3}$ and $\mathrm{S}_{4}$ sulphanilamide caused a decrease in shell weight. A similar drop in 
shell weight occurred in period PS 6 with bird no. 2, which received sulphanilamide and $p$-aminobenzoic acid, but not with birds nos. 3 and 4 , which received only $p$-aminobenzoic acid. However, no statistical analysis was applied to these results for the following reason. The relationship between shell weight and absolute amount of calcium in the shell was tested. From the results shown in Table 4 , it will be seen that this relationship was so definite that there was no need to consider the question of shell weight, since it was a reflexion of shell calcium which is discussed in greater detail later.

Table 3. Mean shell weights for each period ( $g$.)

\begin{tabular}{ccccccc} 
Bird & \multicolumn{7}{c}{ Period } \\
no. & $\mathrm{C}_{\mathbf{I}}$ & $\mathrm{C}_{2}$ & $\mathrm{~S}_{3}$ & $\mathrm{~S}_{4}$ & $\mathrm{R}_{5}$ & PS6 \\
2 & $4.7 \mathrm{I}$ & 4.82 & 3.65 & 3.97 & 5.30 & 3.92 \\
3 & 6.06 & 5.80 & 3.73 & 4.28 & 5.54 & 5.90 \\
4 & 4.98 & 4.77 & 3.54 & 2.71 & 4.61 & 5.05 \\
Mean & 5.25 & 5.13 & 3.64 & 3.65 & 5.15 & $-\dagger$ \\
I & 5.64 & 5.55 & 4.63 & 3.12 & 3.54 & 3.85
\end{tabular}

+ See notes to Table 2 .

Table 4. Relationship between shell calcium (absolute amount), $X$, and shell weight, $Y$

$\begin{array}{ccccc}\begin{array}{c}\text { Bird } \\ \text { no. }\end{array} & \begin{array}{c}\text { Pairs of } \\ \text { readings }\end{array} & \begin{array}{c}\text { Correlation } \\ \text { coefficient }\end{array} & \begin{array}{c}\text { Significance } \\ \text { Regression } \\ \text { equation }\end{array} \\ \mathbf{2} & 14 & 0.9989 & P<0.001 & Y=2.535 X+0.422 \\ 3 & 25 & 0.9988 & P<0.001 & Y=2.518 X+0.383 \\ 4 & 15 & 0.9994 & P<0.001 & Y=2.588 X+0.331 \\ \text { All } & 19 & 0.9983 & P<0.001 & Y=2.450 X+0.516 \\ & 73 & 0.9983 & P<0.001 & Y=2.568 X+0.333\end{array}$

In addition to the thinning of the shell caused by sulphanilamide, a few shell-less eggs were laid when the drug was given, and bird no. I produced others even after the drug was withheld. Hinshaw \& McNeil (1943) have already reported the premature expulsion of eggs by turkeys given sulphanilamide.

Shell quality. A record was kept of the external appearance and the candling appearance of each egg laid. The data are too extensive to present, but the general trends may be summarized as follows. Sulphanilamide feeding immediately tended to produce abnormally pale eggs, and some were almost white. Recovery of normal colour was rapid when the drug was withdrawn. Feeding of sulphanilamide also produced an immediate roughening of the shell. This was particularly marked at one or at both ends, but rarely extended over the whole shell. The roughness decreased when sulphanilamide was no longer fed, but it had not completely disappeared even at the end of a fortnight.

The candling appearance indicated that sulphanilamide feeding led to an increase in the size and number of translucent markings, and this increase was frequently so great at the ends that the markings coalesced to form a translucent patch. Recovery from the effect of the drug was never immediate and the rate of recovery varied considerably from bird to bird. 
When the experiment was planned, it was intended to include a study of shell porosity using the method suggested by Tyler (1945). Unfortunately the thin shells produced when the birds were given sulphanilamide almost invariably cracked when the eggs fell on to the wire base of the cage. This made the determination of porosity impossible.

Calcium. The full details of the calcium balances are given in Table 5. With birds nos. 2-4, intake of calcium was fairly constant from period to period and hence the absolute retention of calcium should be a fair assessment of the behaviour of the birds.

Table 5. Calcium balances

(Mean daily values for each period)

\begin{tabular}{|c|c|c|c|c|c|c|c|}
\hline \multirow{2}{*}{$\begin{array}{c}\text { Bird } \\
\text { no. }\end{array}$} & & \multicolumn{6}{|c|}{ Period } \\
\hline & & $\mathrm{C}_{\text {I }}$ & $\mathrm{C}_{2}$ & $\mathrm{~S}_{3}$ & $\mathrm{~S}_{4}$ & $\mathbf{R}_{\mathbf{5}}$ & PS6 \\
\hline I & $\begin{array}{l}\text { Intake (g.) } \\
\text { Droppings (g.) } \\
\text { Retention (g.) } \\
\text { Eggs (g.) } \\
\text { Balance (g.) }\end{array}$ & $\begin{array}{r}2.07 \\
0.98 \\
1.09 \\
1.40 \\
-0.31\end{array}$ & $\begin{array}{r}1.86 \\
0.77 \\
1.09 \\
1.37 \\
-0.28\end{array}$ & $\begin{array}{r}I .59 \\
0.95 \\
0.64 \\
0.57 \\
+0.07\end{array}$ & $\begin{array}{r}1.84 \\
1.49 \dagger \\
0.35 \\
0.18 \\
+0.17\end{array}$ & $\begin{array}{c}I .98 \\
I .6 I t \\
0.37 \\
0.65 \\
-0.28\end{array}$ & $\begin{array}{r}2.12 \\
1.84 \dagger \\
0.28 \\
0.29 \\
-0.01\end{array}$ \\
\hline 2 & $\begin{array}{l}\text { Intake (g.) } \\
\text { Droppings (g.) } \\
\text { Retention (g.) } \\
\text { Eggs (g.) } \\
\text { Balance (g.) }\end{array}$ & $\begin{array}{r}2 \cdot 47 \\
I \cdot 09 \\
1 \cdot 38 \\
I \cdot 46 \\
-0.08\end{array}$ & $\begin{array}{r}2 \cdot 47 \\
1 \cdot 14 \\
1 \cdot 33 \\
1 \cdot 20 \\
+0 \cdot 13\end{array}$ & $\begin{array}{r}2.29 \\
1.35 \\
0.94 \\
0.89 \\
+0.05\end{array}$ & $\begin{array}{r}2.29 \\
1.66 \\
0.63 \\
0.97 \\
-0.34\end{array}$ & $\begin{array}{r}2.29 \\
1.59 \\
0.70 \\
1.32 \\
-0.62\end{array}$ & $\begin{array}{r}2.31 \\
1.50 \\
0.81 \\
0.96 \\
-0.15\end{array}$ \\
\hline 3 & $\begin{array}{l}\text { Intake (g.) } \\
\text { Droppings (g.) } \\
\text { Retention (g.) } \\
\text { Eggs (g.) } \\
\text { Balance (g.) }\end{array}$ & $\begin{array}{r}2.47 \\
1.59 \\
0.88 \\
1.13 \\
-0.25\end{array}$ & $\begin{array}{r}2.47 \\
1.53 \\
0.94 \\
1.07 \\
-0.13\end{array}$ & $\begin{array}{r}2.29 \\
1.68 \\
0.61 \\
0.67 \\
-0.06\end{array}$ & $\begin{array}{l}2.29 \\
2.04 t \\
0.25 \\
0.53 \\
-0.28\end{array}$ & $\begin{array}{r}2.29 \\
1.78 \\
0.51 \\
0.69 \\
-0.18\end{array}$ & $\begin{array}{r}2.27 \\
1.79 \\
0.48 \\
0.73 \\
-0.25\end{array}$ \\
\hline 4 & $\begin{array}{l}\text { Intake (g.) } \\
\text { Droppings (g.) } \\
\text { Retention (g.) } \\
\text { Eggs (g.) } \\
\text { Balance (g.) }\end{array}$ & $\begin{array}{l}2 \cdot 47 \\
1 \cdot 74 \\
0.73 \\
0.73 \\
0.00\end{array}$ & $\begin{array}{r}2.47 \\
1.65 \\
0.82 \\
1.18 \\
-0.36\end{array}$ & $\begin{array}{c}2.29 \\
1.75 \dagger \\
0.54 \\
0.80 \\
-0.26\end{array}$ & $\begin{array}{r}2.08 \\
1.66 \\
0.42 \\
0.43 \\
-0.01\end{array}$ & $\begin{array}{r}2.29 \\
1.61 \\
0.68 \\
I .15 \\
-0.47\end{array}$ & $\begin{array}{r}2.22 \\
1 \cdot 48 \\
0.74 \\
I \cdot 26 \\
-0.52\end{array}$ \\
\hline
\end{tabular}

$\dagger$ Egg content in droppings on I day in this period.

In Table 6, the mean daily retention values are recorded. Statistical analysis indicates that sulphanilamide lowered the calcium retention significantly during the ist week of its administration. Apparently the effect was cumulative since during the second sulphanilamide period the retention was significantly lower than in the first. On withholding sulphanilamide, there was an increase in calcium retention, but this was not significant, and if period $\mathrm{R}_{5}$ is compared with periods $\mathrm{Cr}_{\mathrm{r}}$ and $\mathrm{C}_{2}$, it will be seen that calcium retention was significantly lower in $\mathrm{R}_{5}$ than in the other two. Bird no. $I$, although its calcium intake fluctuated, showed the same general trend. It is not easy to assess the effect of the two compounds, $p$-aminobenzoic acid and sulphanilamide, together, or of the former alone, on the calcium retention because of the time lag in recovery from the previous dose of sulphanilamide. However, there was little, if any, recovery when $p$-aminobenzoic acid was fed alone.

The next important aspect of this matter is egg-shell calcium and the data for this are also given in Table 6 . These figures refer to calcium per egg-shell, and not calcium in the egg-shell, averaged over the 6 days of a period. There was a highly significant fall 
Table 6. Mean results for calcium retentions and balances and for the amount of calcium present in the egg-shell and egg content for each period

\begin{tabular}{|c|c|c|c|c|c|c|c|c|c|c|}
\hline \multirow{2}{*}{$\begin{array}{c}\text { Bird } \\
\text { no. }\end{array}$} & \multicolumn{10}{|c|}{ Period } \\
\hline & \multicolumn{2}{|l|}{$C_{1}$} & \multirow[t]{2}{*}{$\mathbf{C}_{2}$} & \multicolumn{2}{|c|}{$\mathrm{S}_{3}$} & \multicolumn{2}{|r|}{$\mathrm{S}_{4}$} & \multicolumn{2}{|r|}{$\mathrm{R}_{5}$} & PS 6 \\
\hline \multicolumn{10}{|c|}{ Calcium retention (g.) } & \\
\hline 2 & $1 \cdot 38$ & & $\mathbf{1} \cdot \mathbf{3 3}$ & & 0.94 & & 0.63 & & 0.70 & $0.8 \mathbf{r}$ \\
\hline 3 & 0.88 & & 0.94 & & 0.61 & & 0.25 & & $0.5 \mathrm{I}$ & 0.48 \\
\hline 4 & 0.73 & & & & 0.54 & & 0.42 & & 0.68 & 0.74 \\
\hline Mean & $x \cdot 00$ & N.S. & 1.03 & - & 0.70 & - & 0.43 & N.S. & 0.63 & - \\
\hline $\mathrm{I}$ & & & 1.09 & & 0.64 & & 0.35 & & 0.37 & 0.28 \\
\hline \multicolumn{11}{|c|}{ Calcium in egg-shell (g.) } \\
\hline 2 & $\mathrm{I} \cdot 73$ & & $r \cdot 77$ & & $1 \cdot 30$ & & $1 \cdot 42$ & & $x \cdot 95$ & $1 \cdot 39$ \\
\hline 3 & $2 \cdot 22$ & & $2 \cdot 11$ & & $1 \cdot 30$ & & I.54 & & $2 \cdot 03$ & $2 \cdot 16$ \\
\hline 4 & $x \cdot 43$ & & $1 \cdot 73$ & & $1 \cdot 23$ & & $1 \cdot 22$ & & $1 \cdot 69$ & $\mathrm{I} \cdot 85$ \\
\hline Mean & $1 \cdot 79$ & N.S. & $1 \cdot 87$ & $* *$ & $1 \cdot 28$ & N.S. & $1 \cdot 39$ & $*$ & $x \cdot 89$ & - \\
\hline 1 & 2.06 & & $2 \cdot 02$ & & $x \cdot 66$ & & 1.07 & & $1 \cdot 26$ & $1 \cdot 33$ \\
\hline \multicolumn{11}{|c|}{ Calcium in egg content (g.) } \\
\hline 2 & 0.032 & & 0.035 & & 0.040 & & 0.037 & & 0.034 & 0.039 \\
\hline 3 & 0.038 & & 0.036 & & 0.039 & & 0.036 & & 0.036 & $0.03^{8}$ \\
\hline 4 & 0.036 & & 0.036 & & 0.039 & & 0.041 & & 0.036 & 0.039 \\
\hline Mean & 0.035 & N.S. & 0.036 & N.S. & 0.039 & N.S. & 0.038 & N.S. & 0.035 & - \\
\hline I & 0.032 & & 0.030 & & 0.032 & & 0.037 & & 0.035 & 0.035 \\
\hline \multicolumn{11}{|c|}{ Calcium balance (g.) } \\
\hline 2 & -0.08 & & +0.13 & & +0.05 & & -0.34 & & -0.62 & -0.15 \\
\hline 3 & -0.25 & & -0.13 & & -0.06 & & -0.28 & & -0.18 & -0.25 \\
\hline 4 & 0.00 & & $-0 \cdot 36$ & & -0.26 & & -0.01 & & -0.47 & -0.52 \\
\hline Mean & -0.11 & N.S. & -0.12 & N.S. & -0.09 & N.S. & -0.21 & N.S. & -0.42 & - \\
\hline$I$ & -0.31 & & -0.28 & & +0.07 & & +0.17 & & -0.28 & -0.01 \\
\hline
\end{tabular}

N.S., *, **, "**: see notes to Table 2.

in egg-shell calcium when sulphanilamide was fed, but the level did not fall significantly further in the second period $\left(\mathrm{S}_{4}\right)$ of giving the drug. On the other hand, when the drug was withdrawn the egg-shell calcium showed a significant increase, and in fact returned to the original level. Bird no. I showed a fall in shell calcium in both periods and did not recover to the same extent when the sulphanilamide was withdrawn, the egg-shell calcium remaining low. In period PS6, bird no. 2 receiving $p$-aminobenzoic acid and sulphanilamide again showed a drop in egg-shell calcium as compared with period $R_{5}$, but birds nos. 3 and 4 receiving $p$-aminobenzoic acid alone showed no drop.

It is important to point out here that when soft-shelled eggs were laid, portions of the shell were often eaten and it was, therefore, impossible to include them when mean egg-shell calcium values were being determined. However, in all such instances, their inclusion, had it been possible, would have lowered the mean value and produced even greater differences between the periods with sulphanilamide and the other periods.

A study of the mean calcium values for egg content (Table 6) indicates that there were no significant changes in them.

The mean values for the final balances, nearly all of them negative, are shown in Table 6. It will be observed that none of the differences were significant, but it is of interest to note that there was an improvement in the balance in the first sulphanil- 
amide period $\left(\mathrm{S}_{3}\right)$, a deterioration in the second sulphanilamide period $\left(\mathrm{S}_{4}\right)$ and a serious deterioration when sulphanilamide was withdrawn. Bird no. I, despite her fluctuating intake, gave a somewhat similar picture. With birds nos. 3 and 4 in period PS6, the balance became even more negative.

\section{Table 7. Carbonate retentions and carbonate contents of the shells}

(Retentions are given as mean daily values and shell values as mean shell values for each period)

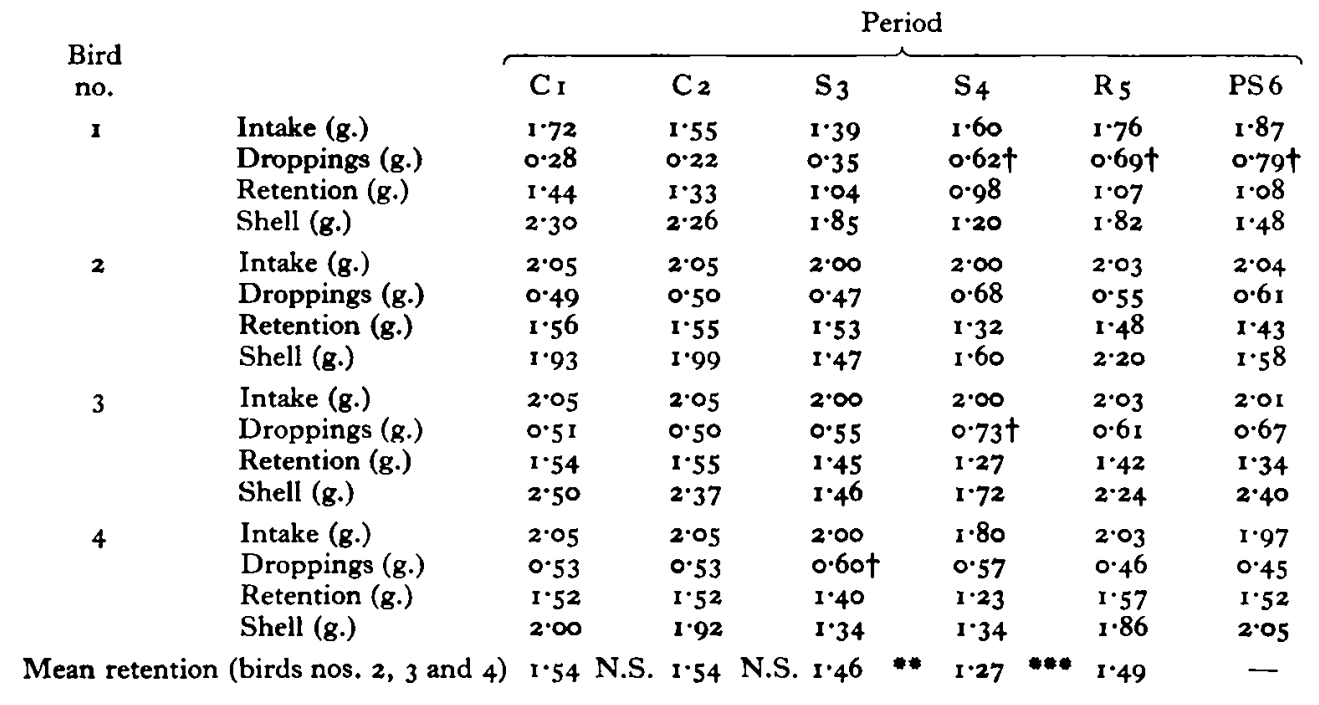

+ Egg content in droppings on 1 day in this period.

N.S., ****: see notes to Table 2.

Carbonate. The production of large quantities of carbon dioxide from organic compounds would completely upset any attempt to strike a carbonate balance even if facilities had been available for the collection of gaseous excreta. Therefore in this experiment, no carbonate balance was struck. However, the retention of carbonate and the amount in the shells were determined. The data are given in Table 7 , where it will be observed that in the first two (control) periods and for birds nos. 2-4, the retention of carbonate was almost constant, not only between periods, but between birds. Then, in the first sulphanilamide period $\left(\mathrm{S}_{3}\right)$, it fell somewhat, but not significantly. In the second sulphanilamide period $\left(\mathrm{S}_{4}\right)$, it fell significantly in comparison with the first and, finally, when the drug was withheld, it increased significantly to almost the control level. In period PS6 compared with period $\mathrm{R}_{5}$ no great changes were observed.

Although it is well known that the egg-shell consists chiefly of calcium carbonate, the relationship between shell calcium and shell carbonate in the present experiments was calculated. The results are shown in Table 8. This relationship is so close that, having discussed egg-shell calcium values, there is no need to consider the corresponding carbonate values.

Phosphorus. The phosphorus data are given in Tables 9 and ro. No significant differences appeared anywhere except in the balance figures and thus sulphanilamide had no effect on phosphorus retention, egg-shell phosphorus or egg-content phosphorus. 
Table 8. Relationship between shell calcium, $X$, and shell carbonate, $Y$

$\begin{array}{ccccc}\begin{array}{c}\text { Bird } \\ \text { no. }\end{array} & \begin{array}{c}\text { Pairs of } \\ \text { readings }\end{array} & \begin{array}{c}\text { Correlation } \\ \text { coefficient }\end{array} & \begin{array}{c}\text { Significance } \\ \text { Regression } \\ \text { equation }\end{array} \\ 2 & 14 & 0.9991 & P<0.001 & Y=1 \cdot 125 X-0.0133 \\ 2 & 25 & 0.9983 & P<0.001 & Y=1.123 X+0.0062 \\ 3 & 15 & 0.9988 & P<0.01 & Y=1.120 X+0.0003 \\ 4 & 19 & 0.9981 & P<0.01 & Y=1.100 X+0.0122 \\ \text { All } & 73 & 0.9983 & P<0.001 & Y=1.118 X+0.0018\end{array}$

However, before leaving this aspect of the experiment attention should be drawn to the considerable, though admittedly not significant, increase in phosphorus retention observed in the first sulphanilamide period as compared with the control period and the return to a more normal value in the second sulphanilamide period (Table ro). This is reflected in the balance data, which show significant differences at these points. A similar increase in phosphorus retention was shown by bird no. 2 when given $p$-aminobenzoic acid and sulphanilamide in period PS6, and this was again reflected in a positive phosphorus balance.

Table 9. Phosphorus balances

(Mean daily values for each period)

\begin{tabular}{|c|c|c|c|c|c|c|c|}
\hline \multirow{2}{*}{$\begin{array}{l}\text { Bird } \\
\text { no. }\end{array}$} & & \multicolumn{6}{|c|}{ Period } \\
\hline & & $\mathbf{C}_{1}$ & $\mathrm{C}_{2}$ & $\mathrm{~S}_{3}$ & $\mathbf{S}_{4}$ & $\mathbf{R}_{5}$ & PS6 \\
\hline \multirow[t]{3}{*}{ I } & $\begin{array}{l}\text { Intake (g.) } \\
\text { Droppings (g.) }\end{array}$ & $\begin{array}{l}0.93 \\
0.8 \mathrm{I}\end{array}$ & $\begin{array}{l}0.83 \\
0.56\end{array}$ & $\begin{array}{l}0.75 \\
0.48\end{array}$ & $\begin{array}{l}0.87 \\
0.73 \dagger\end{array}$ & $\begin{array}{l}0.95 \\
0.81+\end{array}$ & $\begin{array}{l}\text { I.02 } \\
0.89 \dagger\end{array}$ \\
\hline & $\begin{array}{l}\text { Retention (g.) } \\
\text { Eggs (g.) }\end{array}$ & $\begin{array}{l}0.12 \\
0.08\end{array}$ & $\begin{array}{l}0.27 \\
0.08\end{array}$ & $\begin{array}{l}0.27 \\
0.05\end{array}$ & $\begin{array}{l}0.14 \\
0.02\end{array}$ & $\begin{array}{l}0.14 \\
0.06\end{array}$ & $\begin{array}{l}0.13 \\
0.02\end{array}$ \\
\hline & Balance (g.) & +0.04 & +0.19 & +0.22 & +0.12 & +0.08 & +0.11 \\
\hline \multirow[t]{5}{*}{2} & Intake (g.) & $1 \cdot 10$ & $1 \cdot 10$ & $I \cdot 09$ & $1 \cdot 09$ & 1.09 & $I \cdot I I$ \\
\hline & Droppings (g.) & 0.85 & 0.93 & 0.77 & 0.93 & $1 \cdot 07$ & 0.87 \\
\hline & Retention (g.) & 0.25 & 0.17 & 0.32 & 0.16 & 0.02 & 0.24 \\
\hline & Eggs (g.) & 0.11 & 0.09 & 0.09 & 0.09 & 0.09 & 0.09 \\
\hline & Balance (g.) & +0.14 & +0.08 & +0.23 & +0.07 & -0.07 & +0.15 \\
\hline \multirow[t]{5}{*}{3} & Intake (g.) & $I \cdot 10$ & $I \cdot 10$ & $1 \cdot 09$ & $1 \cdot 09$ & $I \cdot 09$ & $\mathrm{I} \cdot 06$ \\
\hline & Droppings (g.) & 0.99 & $1 \cdot 04$ & 0.85 & 1.oIt & $1 \cdot 03$ & 0.94 \\
\hline & Retention (g.) & 0.11 & 0.06 & 0.24 & 0.08 & 0.06 & 0.12 \\
\hline & Eggs (g.) & 0.07 & 0.07 & 0.07 & 0.05 & 0.04 & 0.05 \\
\hline & Balance (g.) & +0.04 & -0.01 & +0.17 & +0.03 & +0.02 & +0.07 \\
\hline \multirow[t]{5}{*}{4} & Intake (g.) & $1 \cdot 10$ & $1 \cdot 10$ & 1.09 & 0.98 & $1 \cdot \infty$ & $1 \cdot 04$ \\
\hline & Droppings (g.) & $1 \cdot 03$ & $1 \cdot 03$ & $0.93 \dagger$ & 0.87 & 0.96 & 0.97 \\
\hline & Retention (g.) & 0.07 & 0.07 & 0.16 & $0 \cdot I_{1}$ & 0.13 & 0.07 \\
\hline & Figgs (g.) & 0.06 & 0.09 & 0.07 & 0.07 & 0.10 & 0.10 \\
\hline & Balance (g.) & +0.01 & -0.02 & +0.09 & +0.04 & +0.03 & -0.03 \\
\hline
\end{tabular}

+ Egg content in droppings on I day in this period.

$C a: P$ ratio in droppings. In a previous paper, Tyler (1948) stated that the Ca: $\mathrm{P}$ ratio of the droppings of laying hens rarely appeared to exceed a value of 2 . It is, therefore, of interest to consider the values for this experiment. They are shown in Table II. The highest value is $2 \cdot 08$, thus giving further evidence of a maximum ratio of about 2.

Chlorides. The detailed data concerning chlorides are set out in Table I 2. There were no significant differences anywhere and tables concerned with statistical analysis have 
Table 10. Mean values for phosphorus retentions and balances and for the amount of phosphorus present in the egg-shell and egg contents for each period

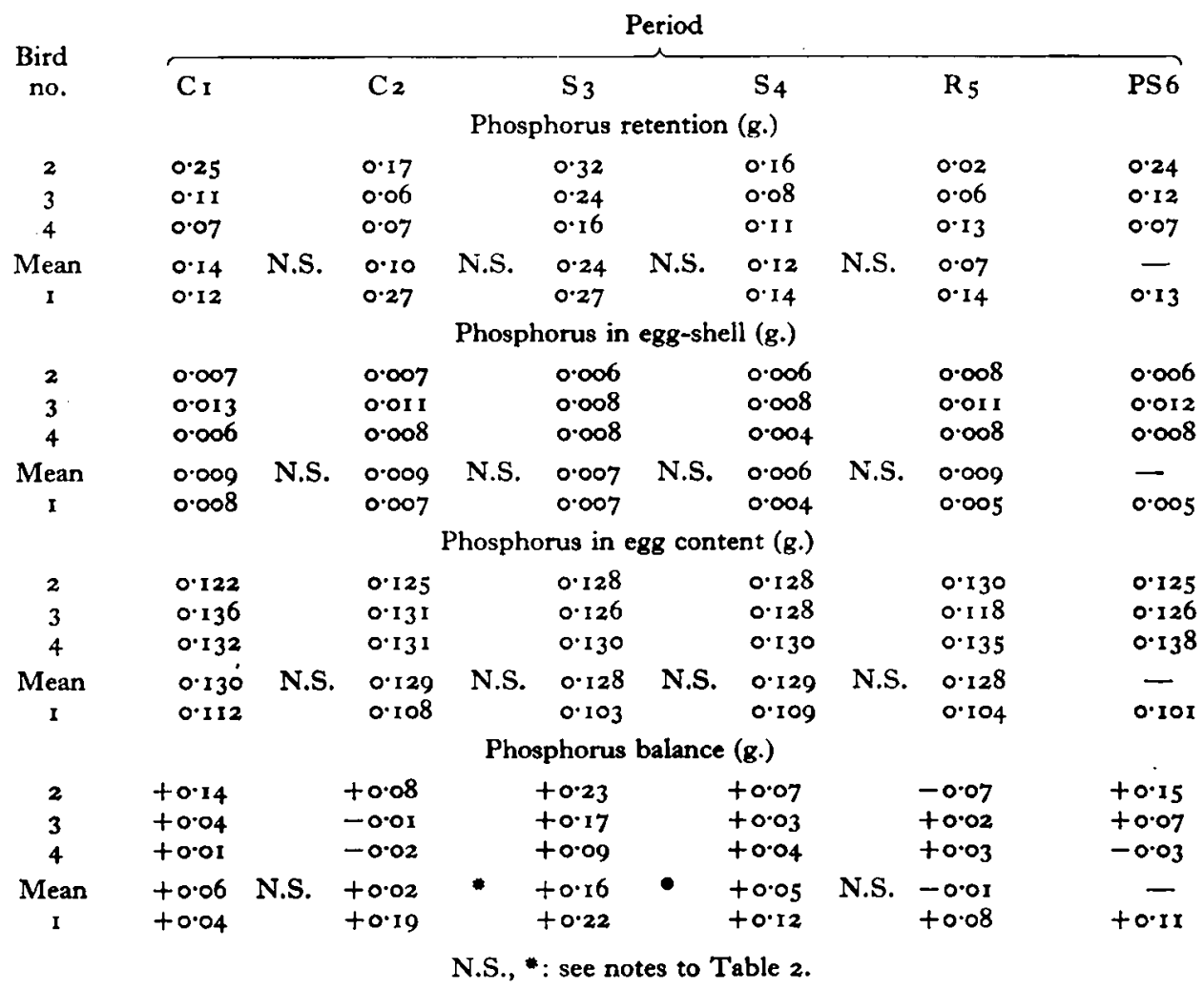

Table II. Calcium: phosphorus ratio of the droppings

(Mean values for each period)

\begin{tabular}{|c|c|c|c|c|c|c|}
\hline \multirow{2}{*}{$\begin{array}{c}\text { Bird } \\
\text { no. }\end{array}$} & \multicolumn{6}{|c|}{ Period } \\
\hline & $C_{1}$ & $\mathrm{C}_{2}$ & $\mathbf{S}_{3}$ & $\mathrm{~S}_{4}$ & $\mathbf{R}_{5}$ & PS6 \\
\hline $\mathbf{I}$ & $1 \cdot 21$ & $r \cdot 36$ & I'98 & $2 \cdot 03$ & $2 \cdot 0$ & $2 \cdot 08$ \\
\hline 2 & $1 \cdot 28$ & $1 \cdot 23$ & $I \cdot 75$ & $x \cdot 79$ & 1.49 & $1 \cdot 73$ \\
\hline 3 & $1 \cdot 61$ & $1 \cdot 47$ & $1 \cdot 97$ & $2 \cdot 02$ & $I \cdot 73$ & $1 \cdot 89$ \\
\hline 4 & $1 \cdot 69$ & $I \cdot 60$ & I.87 & $1 \cdot 90$ & $1 \cdot 67$ & $1 \cdot 53$ \\
\hline
\end{tabular}

therefore been omitted. Mention should be made, however, of the fall in chloride retention when sulphanilamide was fed and of the increase when it was withdrawn.

Nitrogen. Table $\mathrm{r} 3$ gives the full data for nitrogen. The statistical analysis showed no significant differences between periods; tables concerning them have therefore been omitted.

Shell composition. Some general aspects of the shell have already been considered and also the absolute amounts of the various elements it contains, but it is important to study the percentage composition of the shell, to see whether sulphanilamide had effects not brought out by the previous data. 
Table 12. Chloride balances

(Mean daily values for each period)

\begin{tabular}{|c|c|c|c|c|c|c|c|}
\hline \multirow{2}{*}{$\begin{array}{c}\text { Bird } \\
\text { no. }\end{array}$} & & \multicolumn{6}{|c|}{ Period } \\
\hline & & $\mathrm{C}_{\mathrm{I}}$ & $\mathrm{C}_{2}$ & $\mathrm{~S}_{3}$ & $\mathrm{~S}_{4}$ & $\mathrm{R}_{5}$ & PS6 \\
\hline I & $\begin{array}{l}\text { Intake (g.) } \\
\text { Droppings (g.) } \\
\text { Retention (g.) } \\
\text { Eggs (g.) } \\
\text { Balance (g.) }\end{array}$ & $\begin{array}{r}0.402 \\
0.359 \\
0.043 \\
0.061 \\
-0.018\end{array}$ & $\begin{array}{r}0.361 \\
0.303 \\
0.058 \\
0.064 \\
-0.006\end{array}$ & $\begin{array}{r}0.320 \\
0.251 \\
0.069 \\
0.048 \\
+0.021\end{array}$ & $\begin{array}{l}0.370 \\
0.303 \dagger \\
0.067 \\
0.016 \\
+0.051\end{array}$ & $\begin{array}{c}0.410 \\
0.3181 \\
0.092 \\
0.060 \\
+0.032\end{array}$ & $\begin{array}{l}0.427 \\
0.366 \dagger \\
0.061 \\
0.016 \\
+0.045\end{array}$ \\
\hline 2 & $\begin{array}{l}\text { Intake (g.) } \\
\text { Droppings (g.) } \\
\text { Retention (g.) } \\
\text { Eggs (g.) } \\
\text { Balance (g.) }\end{array}$ & $\begin{array}{r}0.479 \\
0.410 \\
0.069 \\
0.076 \\
-0.007\end{array}$ & $\begin{array}{r}0.479 \\
0.401 \\
0.078 \\
0.058 \\
+0.020\end{array}$ & $\begin{array}{r}0.461 \\
0.397 \\
0.064 \\
0.060 \\
+0.004\end{array}$ & $\begin{array}{r}0.461 \\
0.406 \\
0.055 \\
0.056 \\
-0.001\end{array}$ & $\begin{array}{r}0.474 \\
0.416 \\
0.058 \\
0.059 \\
-0.001\end{array}$ & $\begin{array}{r}0.465 \\
0.380 \\
0.085 \\
0.060 \\
+0.025\end{array}$ \\
\hline 3 & $\begin{array}{l}\text { Intake (g.) } \\
\text { Droppings (g.) } \\
\text { Retention (g.) } \\
\text { Eggs (g.) } \\
\text { Balance (g.) }\end{array}$ & $\begin{array}{r}0.479 \\
0.409 \\
0.070 \\
0.053 \\
+0.017\end{array}$ & $\begin{array}{r}0.479 \\
0.405 \\
0.074 \\
0.052 \\
+0.022\end{array}$ & $\begin{array}{r}0.461 \\
0.404 \\
0.057 \\
0.045 \\
+0.012\end{array}$ & $\begin{array}{l}0.461 \\
0.417 \dagger \\
0.044 \\
0.034 \\
+0.010\end{array}$ & $\begin{array}{r}0.474 \\
0.382 \\
0.092 \\
0.034 \\
+0.058\end{array}$ & $\begin{array}{r}0.461 \\
0.412 \\
0.049 \\
0.033 \\
+0.016\end{array}$ \\
\hline 4 & $\begin{array}{l}\text { Intake (g.) } \\
\text { Droppings (g.) } \\
\text { Retention (g.) } \\
\text { Eggs (g.) } \\
\text { Balance (g.) }\end{array}$ & $\begin{array}{r}0.479 \\
0.417 \\
0.062 \\
0.047 \\
+0.015\end{array}$ & $\begin{array}{r}0.479 \\
0.423 \\
0.056 \\
0.058 \\
-0.002\end{array}$ & $\begin{array}{l}0.416 \\
0.419 \dagger \\
0.042 \\
0.045 \\
-0.003\end{array}$ & $\begin{array}{r}0.415 \\
0.353 \\
0.062 \\
0.060 \\
+0.002\end{array}$ & $\begin{array}{r}0.474 \\
0.404 \\
0.070 \\
0.059 \\
+0.011\end{array}$ & $\begin{array}{r}0.45 \mathrm{I} \\
0.390 \\
0.061 \\
0.059 \\
+0.002\end{array}$ \\
\hline
\end{tabular}

+ Egg content in droppings on I day in this period.

Table 13. Nitrogen balances

(Mean daily values for each period)

\begin{tabular}{|c|c|c|c|c|c|c|c|}
\hline $\begin{array}{l}\text { Bird } \\
\text { no. }\end{array}$ & & $\mathrm{C}_{\mathrm{I}}$ & $\mathrm{C}_{2}$ & $\mathrm{~S}_{3}$ & $S_{4}$ & $R_{5}$ & PS6 \\
\hline I & $\begin{array}{l}\text { Intake (g.) } \\
\text { Droppings (g.) } \\
\text { Retention (g.) } \\
\text { Eggs (g.) } \\
\text { Balance (g.) }\end{array}$ & $\begin{array}{r}2.74 \\
2.28 \\
0.46 \\
0.68 \\
-0.22\end{array}$ & $\begin{array}{r}2.46 \\
2.06 \\
0.40 \\
0.67 \\
-0.27\end{array}$ & $\begin{array}{r}2.27 \\
1.80 \\
0.47 \\
0.35 \\
+0.12\end{array}$ & $\begin{array}{r}2.63 \\
2.31 t \\
0.32 \\
0.18 \\
+0.14\end{array}$ & $\begin{array}{r}2.85 \\
2.47 \dagger \\
0.38 \\
0.48 \\
-0.10\end{array}$ & $\begin{array}{r}3.00 \\
2.65 t \\
0.35 \\
0.19 \\
+0.16\end{array}$ \\
\hline 2 & $\begin{array}{l}\text { Intake (g.) } \\
\text { Droppings (g.) } \\
\text { Retention (g.) } \\
\text { Eggs (g.) } \\
\text { Balance (g.) }\end{array}$ & $\begin{array}{r}3.27 \\
2.55 \\
0.72 \\
0.85 \\
-0.13\end{array}$ & $\begin{array}{r}3.27 \\
2.46 \\
0.81 \\
0.70 \\
+0.11\end{array}$ & $\begin{array}{r}3.28 \\
2.49 \\
0.79 \\
0.69 \\
+0.10\end{array}$ & $\begin{array}{r}3.28 \\
2.57 \\
0.71 \\
0.70 \\
+0.01\end{array}$ & $\begin{array}{r}3.29 \\
2.58 \\
0.71 \\
0.70 \\
+0.01\end{array}$ & $\begin{array}{r}3.27 \\
2.56 \\
0.71 \\
0.72 \\
-0.01\end{array}$ \\
\hline 3 & $\begin{array}{l}\text { Intake (g.) } \\
\text { Droppings (g.) } \\
\text { Retention (g.) } \\
\text { Eggs (g.) } \\
\text { Balance (g.) }\end{array}$ & $\begin{array}{l}3.27 \\
2.72 \\
0.55 \\
0.55 \\
0.00\end{array}$ & $\begin{array}{r}3.27 \\
2.74 \\
0.53 \\
0.56 \\
-0.03\end{array}$ & $\begin{array}{r}3.28 \\
2.69 \\
0.59 \\
0.53 \\
+0.06\end{array}$ & $\begin{array}{r}3.28 \\
2 \cdot 98 t \\
0.30 \\
0.37 \\
-0.07\end{array}$ & $\begin{array}{r}3.29 \\
2.60 \\
0.69 \\
0.34 \\
+0.35\end{array}$ & $\begin{array}{r}3.29 \\
2.83 \\
0.46 \\
0.37 \\
+0.09\end{array}$ \\
\hline 4 & $\begin{array}{l}\text { Intake (g.) } \\
\text { Droppings (g.) } \\
\text { Retention (g.) } \\
\text { Eggs (g.) } \\
\text { Balance (g.) }\end{array}$ & $\begin{array}{r}3.27 \\
2.64 \\
0.63 \\
0.48 \\
+0.15\end{array}$ & $\begin{array}{r}3.27 \\
2.61 \\
0.66 \\
0.69 \\
-0.03\end{array}$ & $\begin{array}{c}3.28 \\
2.79 \dagger \\
0.49 \\
0.53 \\
-0.04\end{array}$ & $\begin{array}{r}2.95 \\
2.48 \\
0.47 \\
0.51 \\
-0.04\end{array}$ & $\begin{array}{l}3.29 \\
2.60 \\
0.69 \\
0.69 \\
0.00\end{array}$ & $\begin{array}{r}3.22 \\
2.57 \\
0.65 \\
0.70 \\
-0.05\end{array}$ \\
\hline
\end{tabular}

$\dagger$ Egg content in droppings on I day in this period. 
Table i 4 shows the data for the percentage of nitrogen in the shell. Sulphanilamide clearly affected it significantly, causing an increase when it was given and a decrease following withdrawal. Further, $p$-aminobenzoic acid did not counteract the effect of the sulphanilamide on bird no. 2 in period PS6. On the other hand, Table 14 indicates that sulphanilamide did not affect the absolute amount of nitrogen in the shell. Now in these experiments the shell consisted of shell with the membranes and by far the greater proportion of the so-called shell nitrogen was in the membrane. It follows, therefore, that the membrane was remaining fairly constant in amount and that the increase in the percentage of nitrogen in the shell was really caused by a decrease of mineral matter in the shell and membrane together.

Table 14. Absolute amount of nitrogen and the percentage of nitrogen in the shells

(Mean shell values for each period)

\begin{tabular}{|c|c|c|c|c|c|c|c|c|c|c|}
\hline \multirow{2}{*}{$\begin{array}{c}\text { Bird } \\
\text { no. }\end{array}$} & \multicolumn{10}{|c|}{ Period } \\
\hline & $\mathrm{C}_{\mathrm{I}}$ & & $\mathrm{C}_{2}$ & & $\mathrm{~S}_{3}$ & & $\mathrm{~S}_{4}$ & & $\mathrm{R}_{5}$ & PS6 \\
\hline \multicolumn{11}{|c|}{ Absolute amount (g.) } \\
\hline 2 & 0.037 & & 0.037 & & 0.040 & & 0.040 & & 0.039 & 0.043 \\
\hline 3 & 0.047 & & 0.045 & & 0.046 & & 0.040 & & 0.043 & 0.045 \\
\hline 4 & 0.046 & & 0.046 & & 0.047 & & 0.052 & & 0.045 & 0.045 \\
\hline Mean & 0.043 & N.S. & 0.043 & N.S. & 0.044 & N.S & 0.044 & N.S. & 0.042 & - \\
\hline I & 0.046 & & 0.049 & & 0.054 & & 0.049 & & 0.051 & 0.044 \\
\hline \multicolumn{11}{|c|}{ Percentage } \\
\hline 2 & 0.78 & & 0.76 & & $1 \cdot 13$ & & $1 \cdot 02$ & & 0.73 & $\mathbf{I} \cdot \mathbf{I} \mathbf{I}$ \\
\hline 3 & 0.78 & & $0.7^{8}$ & & $I \cdot 25$ & & $I \cdot 69$ & & 0.78 & 0.76 \\
\hline 4 & $1 \cdot 00$ & & 0.95 & & 1.40 & & $2 \cdot 12$ & & 0.08 & 0.90 \\
\hline Mean & 0.85 & N.S. & .0 .83 & $*$ & $1 \cdot 26$ & N.S. & $I \cdot 6 I$ & $* *$ & 0.83 & - \\
\hline I & 0.82 & & 0.88 & & $I \cdot 17$ & & $I \cdot 58$ & & $1 \cdot 60$ & $2 \cdot 11$ \\
\hline
\end{tabular}

With this in mind, it is of interest to study the question of shell mineral matter itself, basing the study on values expressed in terms of percentage in the nitrogen-free shell.

In Table ${ }_{5}$ the remarkable constancy of the percentage calcium values is shown. There were no significant differences between periods or between birds. The very close correlation between shell calcium and shell carbonate has already been pointed out (Table 8), and hence the constancy of calcium would be paralleled by that of carbonate. It can be stated, therefore, that sulphanilamide had no effect on either the percentage of calcium or carbonate in the nitrogen-free shell.

With regard to the percentage of phosphorus and chloride in the shell mineral matter, there were again no significant differences between periods, but the values tended to fluctuate far more than those for calcium and carbonate.

Egg-content composition. The data are shown in Table I6. It will be seen that the calcium percentage of the egg content was significantly increased on first giving sulphanilamide, but that it then decreased. The increase was also observed when $p$-aminobenzoic acid and sulphanilamide were given in period PS6. The phosphorus, chloride and nitrogen percentages were not affected. 
Table 15. Percentages of calcium, phosphorus and chloride in the nitrogen-free shell

(Mean shell values for each period)

Period

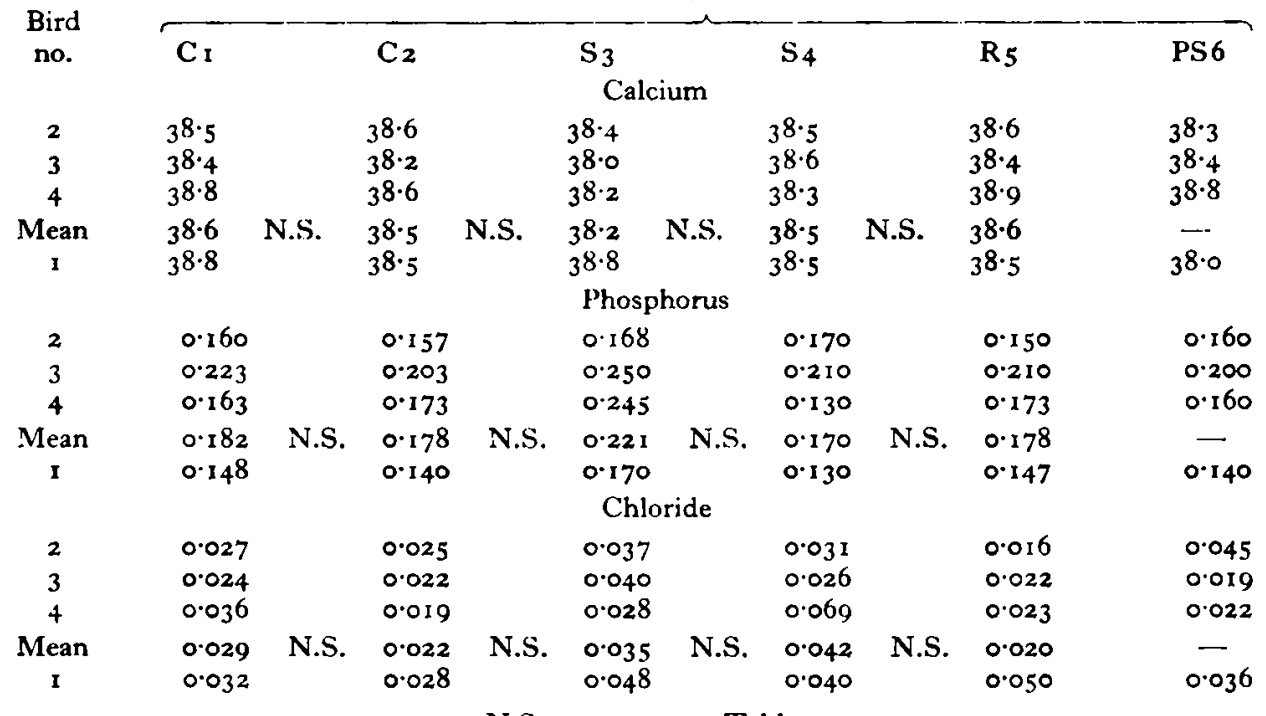

N.S.: see notes to Table 2.

Table 16. Percentages of calcium, phosphorus, chloride and nitrogen in the egg content (Mean egg values for each period)

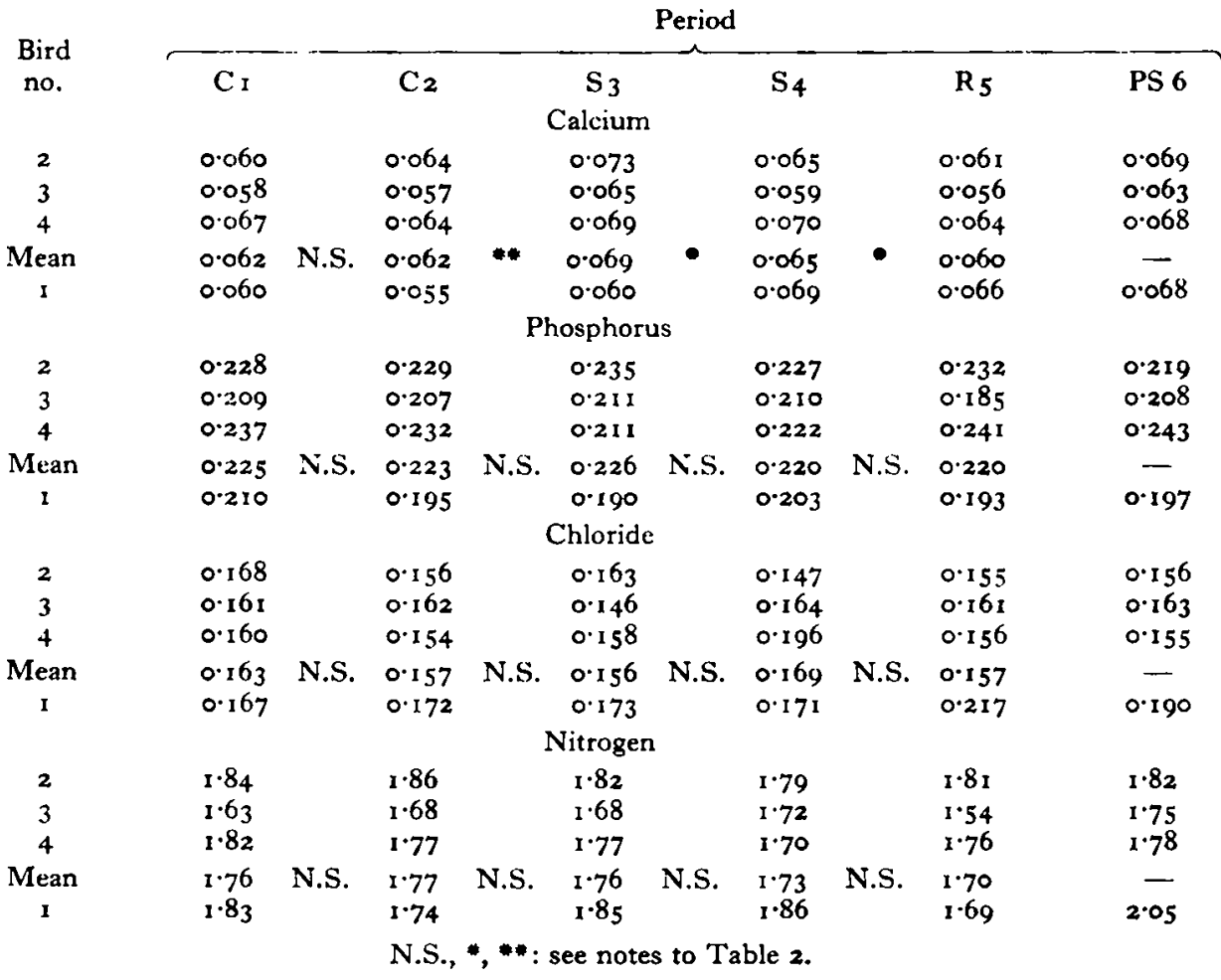


DISCUSSION

The results of these experiments show that sulphanilamide when given at a level of $0.03 \%$ of the dry matter of the ration had a significant effect on the calcium and carbonate metabolism of the laying hen, but that the phosphorus, chloride and nitrogen values were not significantly affected, with the exception of the phosphorus balance. The final period of the experiment (PS6) also gave a strong indication that $p$-aminobenzoic acid was quite unable to counteract the effects of sulphanilamide, and further, that $p$-aminobenzoic acid alone had no apparent effect on the birds.

The drug depressed the retention of calcium and carbonate and the calcium and carbonate in the egg-shell, but these effects did not occur simultaneously. When sulphanilamide was first fed (period $S_{3}$ ), there was an immediate, large and significant decrease in calcium retention and in the shell calcium and carbonate (thinner shells), but the decrease in carbonate retention was much smaller and not significant. During the second sulphanilamide period $\left(\mathrm{S}_{4}\right)$, the calcium retention fell even further and was significantly lower than in period $\mathrm{S}_{3}$; the decrease in carbonate retention was also significant, but in this second period there was no further significant decrease in shell calcium and carbonate. On withholding the drug, carbonate retention returned approximately to the control level; shell calcium and carbonate did the same, but calcium retention, although increasing, did not show a return to normal, and the rise, in any case, was not significant.

The failure of these changes to keep in step had a pronounced effect on the calcium balance, and despite a lack of statistical significance in the results it is essential that calcium balance should be discussed. During the first period on sulphanilamide $\left(\mathrm{S}_{3}\right)$ the lower calcium retention tended to be cancelled out by the lower amount of calcium lost in the egg (chiefly shell calcium). In fact there was a slight improvement in the balance in this period. However, in the second sulphanilamide period $\left(\mathrm{S}_{4}\right)$ there was a much more adverse balance because retention decreased further, whereas the loss in the eggs did not. When sulphanilamide was withdrawn $\left(R_{5}\right)$ the balance became very much worse, for at this stage the losses due to egg calcium had returned to their normal level, but the calcium retention was still very low. Sulphanilamide feeding thus appeared to affect seriously the calcium balance of the laying hen, but the point of greatest interest is that the most serious situation developed after the drug was withdrawn. Unfortunately, the recovery period $\mathrm{R}_{5}$ ended the main experiment and it was therefore impossible to assess the time taken for recovery from the effects of the drug. However, during a further week, two of the birds received $p$-aminobenzoic acid alone and in that week recovery did not appear to take place. Another experiment is now in progress to determine the length of the recovery period.

Although most of the phosphorus changes were not found significant, mention has been made of the higher retention of phosphorus which occurred in the first sulphanilamide period and which was reflected in significant differences in the phosphorus balance. It is now well known that shell formation is accompanied by a heavy excretion of phosphorus (Common, 1933; Tyler \& Willcox, 1942) and that this excretion is much less when thin-shelled eggs are laid. Thus, a lowered excretion would mean a higher 
retention, and it is, therefore, not surprising that this higher retention, and hence greater positive balance, were obtained when sulphanilamide caused thinner-shelled eggs to be laid. However, the absence of the effect in the second sulphanilamide period considerably complicates the issue.

While on this subject of phosphorus excretion, mention should be made of the calcium: phosphorus ratio of the droppings. The first period of sulphanilamide feeding produced a condition of high calcium and low phosphorus excretion. Yet despite this, the calcium:phosphorus ratio of the droppings did not greatly exceed the value of 2 , which Tyler (1948) had found to be a maximum under much more normal conditions.

It is perhaps surprising that the chloride values were not significantly affected by giving sulphanilamide, since it is well known that carbonic anhydrase influences the secretion of hydrochloric acid in the gastric juice (Davenport, 1943) and plays its part in the chloride-bicarbonate shift between blood plasma and corpuscles. However, note has already been taken of a lowered retention when the drug was given, and it is important to remember that any effect on gastric secretion may pass unnoticed in a balance experiment. Much of the chloride secreted in the gastric juice is reabsorbed lower down the tract and if these two effects are balanced, the retention figure for chloride will give no clue to changes in secretion or absorption and only studies of the material in the tract itself, such as those performed by Tyler (1946), will produce the necessary information. On the other hand, it is well to remember that the lowered calcium retention may be a manifestation of some effect on gastric secretion or intestinal absorption of chloride.

The increase in the percentage of nitrogen in the shell when sulphanilamide was given must be regarded as a reflexion of the decrease in true shell material in relation to a constant shell membrane. Nevertheless, with calcium and carbonate, it is of great interest to note that the composition of the mineral matter itself, despite fluctuation in amount caused by the giving of sulphanilamide, was almost constant. 'The relationship between calcium and carbonate is also of importance, if only because it gives strong support to the established fact that the shell is chiefly composed of calcium carbonate. It also showed that there is a slight excess of carbonate over that required to form calcium carbonate.

Phosphorus and chloride percentages in the shell were also unaffected by sulphanilamide, so that the mineral matter appeared to be of almost constant composition. Nevertheless, the phosphorus and chloride showed relatively greater fluctuations and it may be that the whole, or more probably part, of the phosphorus and chloride in the shell is of an adventitious nature, being picked up by the shell on its passage from the shell gland and out of the cloaca.

The increased percentage of calcium in the egg content when sulphanilamide was given is worthy of note, since it is probably another aspect of the general disturbance of calcium metabolism.

Much more work will have to be done on the effect of sulphanilamide on calcium and carbonate metabolism before sound theories can be put forward concerning its mechanism. Nevertheless, a few comments and tentative suggestions can be advanced at this stage. The effects of sulphanilamide on calcium retention, carbonate retention and shell calcium and carbonate do not appear and disappear simultaneously. Therefore, 
if these effects are due to the influence of sulphanilamide on carbonic anhydrase, the onset time and recovery time must vary in various parts of the body. On the other hand, it seems more likely that the differences may be due to the effect of the drug on different enzyme systems.

Such speculation still leaves out of account the actual chain of events leading to lowering of calcium retention. The obvious explanation is that retention is low because subnormal amounts of calcium are required by the shell gland to produce thin-shelled eggs, but this is ruled out by the failure of the retention to return to normal when the shells return to normal. When Davenport \& Fisher (1938-9) suggested that carbonic anhydrase played a part in gastric secretion, it was thought that sulphanilamide would inhibit this secretion, but experiments by Feldberg, Keilin \& Mann (1940) and by Davenport (I94I) failed to show complete inhibition. Nevertheless, there may be a partial inhibition which may lead to a lowered calcium retention by lowering absorption. but if this is so, recovery of the enzyme in the secreting cells of the stomach wall is not so rapid as that of the enzyme in the cells of the shell gland, owing either to a time lag or to a different enzyme system. Another possibility is that storage of calcium by bone may be affected by sulphanilamide and a decrease in this capacity could affect retention.

Clearly much work will be needed before such speculations can be proved or disproved.

\section{SUMMARY}

I. A study was made of the effect of sulphanilamide on the metabolism of calcium, carbonate, phosphorus, chloride and nitrogen in laying hens. In a final period the effect of $p$-aminobenzoic acid alone or with sulphanilamide was also studied.

2. Sulphanilamide significantly depressed the retention of calcium and carbonate and also led to the production of thin-shelled eggs, but these changes did not occur simultaneously, and this was particularly noticeable when sulphanilamide was withdrawn from the diet, as shells then became normal again, but calcium retention remained low, giving rise to a very adverse calcium balance.

3. Apart from a significant increase in the phosphorus balance on giving sulphanilamide, there were no other effects on the metabolism of this element.

4. Sulphanilamide did not significantly influence any aspect of chloride or nitrogen metabolism studied.

5. The increase in percentage of nitrogen in the egg-shell (with membranes) when sulphanilamide was given was primarily due to a fall in true shell material which was not accompanied by any change in the shell membrane.

6. The percentage composition of the nitrogen-free shell, particularly the calcium and carbonate values, remained almost constant throughout the experiment and was, therefore, not affected by sulphanilamide.

7. The percentage composition of the egg content was not influenced by sulphanilamide, except for egg calcium which was significantly increased.

8. The effects produced by sulphanilamide did not appear to be counteracted by the feeding of $p$-aminobenzoic acid at the same time, nor did $p$-aminobenzoic acid alone appear to have any effect. 
9. It is concluded that sulphanilamide profoundly affects the calcium and carbonate metabolism of the laying hen, but an explanation of the mechanisms involved must await further work.

Much work was entailed in collecting and analysing the material, and it is a pleasure to acknowledge the invaluable help of Messrs F. H. Geake, C. J. E. Hand, M. J. Head and $\mathbf{R}$. Hill.

\section{REFERENCES}

Benesch, R., Barron, N. S. \& Mawson, C. A. (1944). Nature, Lond., I53, 138.

Collins, S. H. (1906). f. Soc. chem. Ind., Lond., 25, 518.

Cornmon, R. H. (1933). F. agric. Sci. 23, 555.

Davenport, H. W. (1941). Amer. F. Physiol. 133, 257.

Davenport, H. W. (1943). Gastroenterology, 1, 383 .

Davenport, H. W. \& Fisher, R. B. (1938-9). F. Physiol. 94, 16 P.

Davies, W. L. (1932). Analyst, 57, 79.

Feldberg, W., Keilin, D. \& Mann, 'T. (1940). Nature, Lond., 146, 651.

Gerritz, H. W. (1935). Industr. Engng Chem. (Anal. ed.), 7, 167.

Hinshaw, W. R. \& McNeil, E. (1943). Poult. Sci. 22, 29 r.

Kitson, R. E. \& Mellon, M. G. (1944). Industr. Engng Chem. (Anal. ed.), 16, 379.

Koenig, R. A. \& Johnson, C. R. (1942). Industr. Engng Chem. (Anal. ed.), 14, 55.

Mann, T. \& Keilin, D. (1940). Nature, Lond., 146, 164.

Peters, J. P. \& Van Slyke, D. D. (1932). Quantitative Clinical Chemistry, Vol. 2, Methods. London: Baillière, Tindall and Cox.

Scott, H. M., Jungherr, E. \& Matterson, L. D. (1944). Poult. Sci. 23, 446.

Tyler, C. (1945). F. agric. Sci. 35, 168.

Tyler, C. (1946). F. agric. Sci. 36, 275 .

Tyler, C. (1948). Ұ. agric. Sci. 38, 37 .

Tyler, C. (1948-9). Nutr. Abstr. Rev. 18, 473.

Tyler, C. \& Willcox, J. S. (1942). f. agric. Sci. 32, 43.

Wheatley, V. R. (1 944). Analyst, 69, 207.

Willcox, J. S. (1934). Y. agric. Sci. 24, 636. 